\title{
DÜBLIN
}

Technological University Dublin

ARROW@TU Dublin

2018-04-30

\section{The US's Economic Promises Are Over: an Interview with Miguel Luciano}

\author{
Marisa Lerer \\ Manhattan College \\ Conor McGarrigle \\ Technological University Dublin, conor.mcgarrigle@tudublin.ie
}

Follow this and additional works at: https://arrow.tudublin.ie/aaschadpart

Part of the Art Practice Commons, Contemporary Art Commons, Fine Arts Commons, Interactive Arts Commons, Interdisciplinary Arts and Media Commons, Latina/o Studies Commons, Painting Commons, and the Sculpture Commons

\section{Recommended Citation}

Marisa Lerer \& Conor McGarrigle. (2018). The US's Economic Promises Are Over: an Interview with Miguel Luciano, Visual Resources34:1-2, 143-156, DOI: 10.1080/01973762.2018.1451966

This Article is brought to you for free and open access by the Fine Arts at ARROW@TU Dublin. It has been accepted for inclusion in Articles by an authorized administrator of ARROW@TU Dublin. For more information, please contact arrow.admin@tudublin.ie, aisling.coyne@tudublin.ie,gerard.connolly@tudublin.ie.

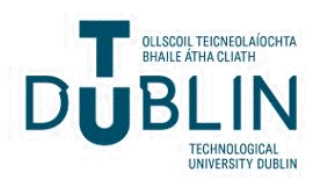




\title{
The US's Economic Promises Are Over: An Interview with Miguel Luciano
}

\author{
Marisa Lerer \& Conor McGarrigle
}

Preprint Version to cite this article: Marisa Lerer \& Conor McGarrigle (2018) The US's Economic Promises Are Over: An Interview with Miguel Luciano, Visual Resources, 34:1-2, 143-156, DOI: $10.1080 / 01973762.2018 .1451966$ 


\title{
The US's Economic Promises Are Over: An Interview with Miguel Luciano
}

\author{
Marisa Lerer and Conor McGarrigle
}

\begin{abstract}
Hurricane Maria struck Puerto Rico in September 2017. The island was left without electricity and clean water for months. However, the natural disaster was not the only cause of this lasting devastation. The financial fall-out from predatory loans, which led to Puerto Rico's inability to invest funds in its own infrastructure, caused an enduring humanitarian disaster. Artist Miguel Luciano (b. 1972) in this interview discusses his work in relation to the 2017 Puerto Rican debt crisis and the legacy of the over 100-year span of Puerto Rico's colonial status as a US territory, which gives the US disproportionate control over the island's economy. Luciano's aesthetic economic investigations also examine the impact of the financial crisis and immigration on the Puerto Rican diaspora living in the US mainland.
\end{abstract}

Keywords: Hurricane Maria; Miguel Luciano; Méndez v. Westminster; Puerto Rican Debt Crisis; Community Action Workshop; Piragua Cart

Your work often calls attention to the history of US colonialism and its connection to neoliberal policies in Puerto Rico. Within that frame, you address economic crisis on multiple levels. Could you first discuss how your work calls attention to the economies functioning outside of regulatory frameworks that impact individual livelihoods, such as the street vending economy in the neighborhood of Bushwick, Brooklyn where your studio is located? We are thinking specifically of Pimp My Piragua (2008-2009), which encapsulates issues such as those who migrate to the US mainland in search of economic stability and at the same time work outside of legal channels. You yourself actually perform the street vendor urban economy, which is a business model that many people turn to in order to survive in a weak economy. ${ }^{1}$

The politics of Pimp My Piragua (Figure 1) are rarely discussed or examined. Essentially, it is a project that honors Latino migrant histories in this city, and innovations born out of cultural and economic necessity. Our migration is in focus right now because we're seeing the fastest paced migration from Puerto Rico to the US mainland since the 1950s. It is even faster than the great migration of the 1940s-1960s, when a million Puerto Ricans - a quarter of the population - migrated to the US. And this was before the hurricanes hit. Since that time, more than 200,000 Puerto Rican residents have migrated to Florida alone. 

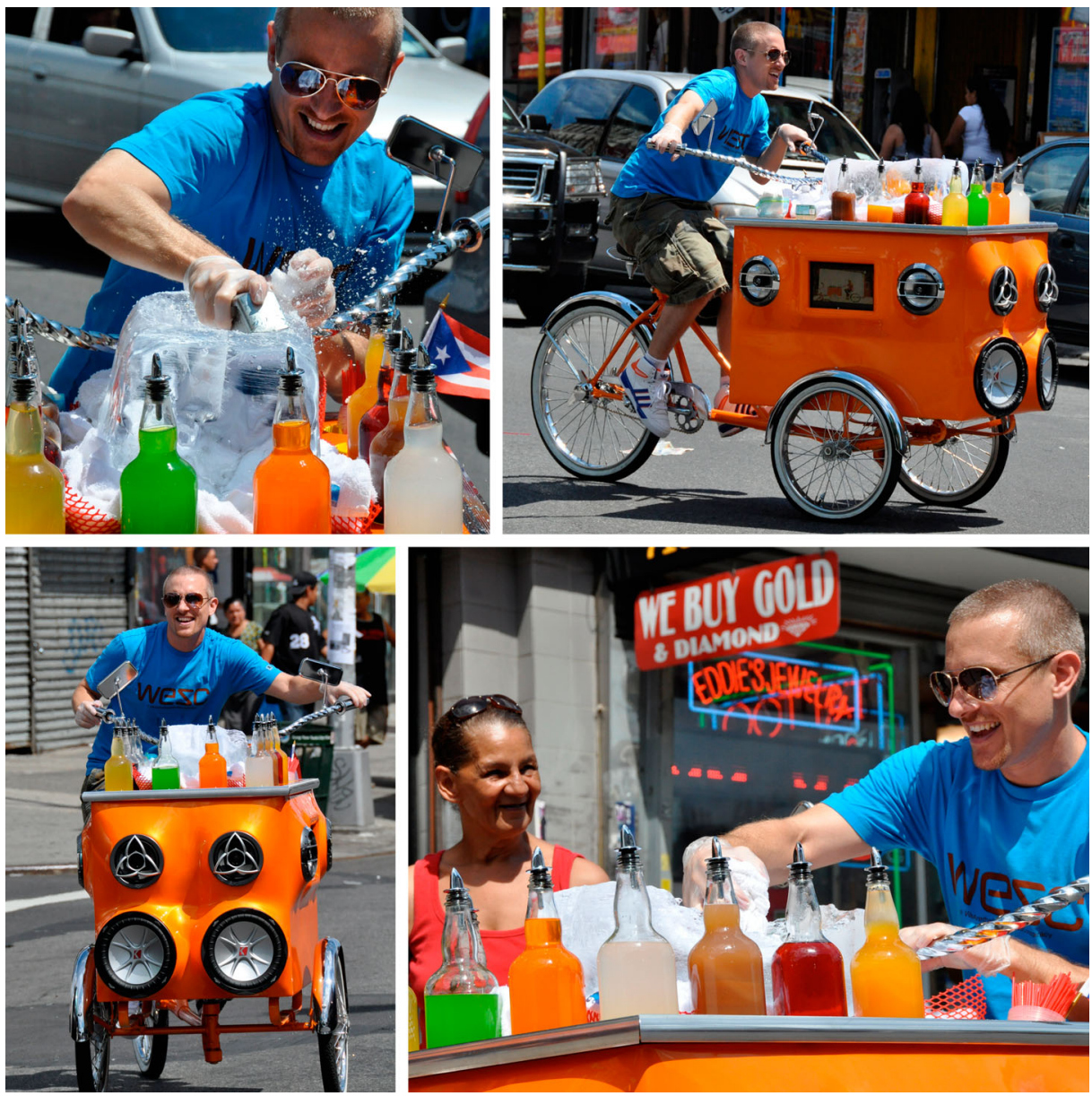

Figure 1. Miguel Luciano, Pimp My Piragua (2008-2009). Customized pushcart tricycle, sound system, video, LEDs. Image: Courtesy of the artist.

Is our contemporary moment's immigration influx in direct response to the island's economic crisis?

Exactly, migration was a response to the economic crisis in the 1950s as well, and reinforced by Operation Boot Strap, a US government-supported labor program. They filled planes and boats with people who came in large numbers to work in factories and farms. It provided cheaper labor to those industries in the US and it was also supposed to help resolve high unemployment rates on the island, providing jobs to those in need; that was the way it was pitched. My family came here during that time, as did many, and worked in those types of jobs in factories. Then those jobs disappeared and eventually the economy changed and shifted and there were not jobs to replace them. A lot of people fell into poverty in serious ways afterwards. By the 1960s and 1970s, the jobs dried up and people were figuring out how to survive. From the very beginning though, you have informal kinds of neighborhood economies, where people have innovated for cultural and economic survival. 
The homemade push carts and street vending carts, and of course the piragua [snow cone] carts were among those first examples and were some of the very first startup businesses for Latino migrants - Puerto Ricans specifically - in New York City.

Somewhere I have a beautiful black and white photo from the Centro [Centro de Estudios Puertorriqueños/Center for the Study of Puerto Ricans, Hunter College, City University of New York] Archives from the 1920s, of a piragua vendor on the West Side. For almost 100 years these businesses have been around, but never have they been officially licensed. For me, that was a really interesting thing to think about in this project. I was living in Bushwick where I still have my studio. It is not far from the Southside of Williamsburg [Brooklyn, NY], which was also a neighborhood that my family was connected to. My Uncle Hector was an activist, organizer, and educator in the late 1960s and 1970s in Los Sures - in the Southside - and so I remember visiting him in the early 1980s, which was a whole other Williamsburg. The piragua cart and Pimp my Piragua is really a project that is inspired by the community that I live in and that my family has lived in as well. It is inspired by Puerto Rican culture that persists in New York, and is an homage to our traditions. And is a proud and celebratory way of commemorating our culture. The dwindling number of piragua carts in the street tells you about the impact of gentrification. They are something of a barometer of gentrification in that respect, because the piragüeros [piragua vendors] who you used to see on the same corner, summer after summer, are starting to disappear. I knew one piragua vendor who was from the Dominican Republic (DR), who came seasonally to work and would then go back to the DR in winter and live from her earnings. Those things started to shift as more of our people are getting squeezed out. So fewer Latinos, fewer piraguas, fewer bodegas, and fewer examples of things that had been around supporting our community for a long time as the community gets pushed out. Part of this project was an homage to this tradition in order to keep our culture strong and present.

\section{Could you discuss the performative and public nature of your practice?}

It is a very public and performative celebration with music, videos, and delicious piraguas. It is still a traditional, fully functional cart, but it has a lot of fancy things on it that reflect the flamboyance of custom car and bike culture, and a sound system that can turn into a block party. All these elements come together in a way that really just reflects back on the culture that is already there. For me that was one of the most important aspects of this as a public art project - that it returns to the community that inspired it. It was really built for that. It does travel to museum spaces and galleries, and I love it in those spaces too, but it is never the same kind of project. If you really want to experience the full energy of the project, you have to see it in its original environment. For me, it is a really special thing and it needs no translation. That is the irony also, because when it is in gallery, it needs a translation and an explained context (Figure 2). I like that it can move in between these different spaces and it can also honor us in these other spaces, where we often feel less welcome. It is important for me as well to make these kinds of proud statements about who we are and what our experience is through these objects. I love connecting with people through the work. Making work that is a direct interaction and exchange has always been really important to 


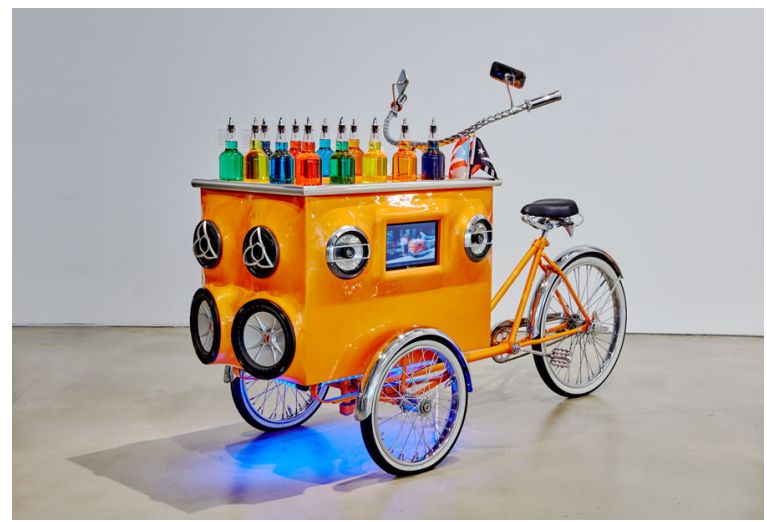

Figure 2. Miguel Luciano, Pimp My Piragua (2008-2009). Customized pushcart tricycle, sound system, video, LEDs. Image: Courtesy of the artist.

me and it gets back to these core interests in social engagement and art being a unique vehicle for this. If you can activate a space that gets people excited about culture, politics, social justice, or other kinds of issues that are important for our survival, then the artwork is performing multiple roles.

Something that happens every time with the piragua cart, which still surprises me, is that you never know what kind of conversations you will have with people. It is a way to learn about your community informally because not everyone knows that I am an artist. I am the guy with the fancy piragua cart, but I am still selling piraguas and part of the nature of that business is about the exchanges. You have a conversation even if it is only for a few minutes, but you are constantly connected with people and in those informal conversations you often have some really special exchanges. For example, last weekend there was an elderly woman who grew up in Harlem and when I was taking a break and standing next to the bike, she asked me to move out of the way so that she could take a picture of the cart by itself. I of course obliged, and she came up to me afterwards and started talking to me about why she was taking the picture. Again, she did not know that I was the artist and I do not even know if she knew this was a public art project - it is sometimes just a fancy piragua cart - and that is okay too. She started telling me stories about how nostalgic she was about the shaved ice. It was something that she grew up around and her father and mother had a piragua cart. She started to get emotional and that blew me away too. She said that is what put food on the table when they were kids. I was really moved, and it reminded me about how these kinds of informal business are real livelihoods for people and they have been for us, for a long time. Sometimes I experience these unexpected stories, which reminds me of why I made the work to begin with.

\section{Have you been documenting these stories that emerge within the context of per- forming your work?}

No, I should, but I have not very much. The more typical kind of questions I get are: Who made it? How much did it cost? Can you make me one? People are really inspired 
by the technical innovation and by the idea that this could also be an exciting entrepreneurial venture, which is the least interesting thing for me to think about. The whole gesture of that work on the other hand is about the fantasy of this experience. It is the "pimped out" piragua cart. It is so decked out with all this fancy equipment for a very humble sort of profession. But it is also about the idea of elevating the experience, creating a decadent experience out of an everyday object, and I love that too. I like going back and forth thinking about those things. Part of me made it with some criticality of our material and consumer fetishes; it is really about the value of culture in relation to everything. But, the truth is that I am also completely enamored with the aesthetics of hooked-up bikes and cars, and the creativity you see in this space. So there is room for all of it in the work.

You mentioned Operation Boot Strap, when the US brought laborers from Puerto Rico to engage with the main land's agricultural economy. This connection between colonialism and Puerto Rican laborers in the US extends historically to the agricultural economy on the mainland. How did you unearth this under-taught history and how do your projects address this critical, but somewhat historically buried connection between Puerto Rico and the United States?

Porto Rican Cotton Picker (2011, Figure 3) is actually a work that addresses migrations that preceded Operation Boot Strap. The title is based on a bike Schwinn made in the 1970 s called the Cotton Picker. Politically incorrect even in the '70s, it was discontinued after two years, which made it a rare item in the vintage bike world (Figure 4). I learned about the bike through friends in the Puerto Rican Schwinn Clubs in Brooklyn - which



Figure 3. Miguel Luciano, Porto Rican Cotton Picker (2011). 1971 Schwinn Cotton Picker, restored and customized, flags. Image: Courtesy of the artist. 


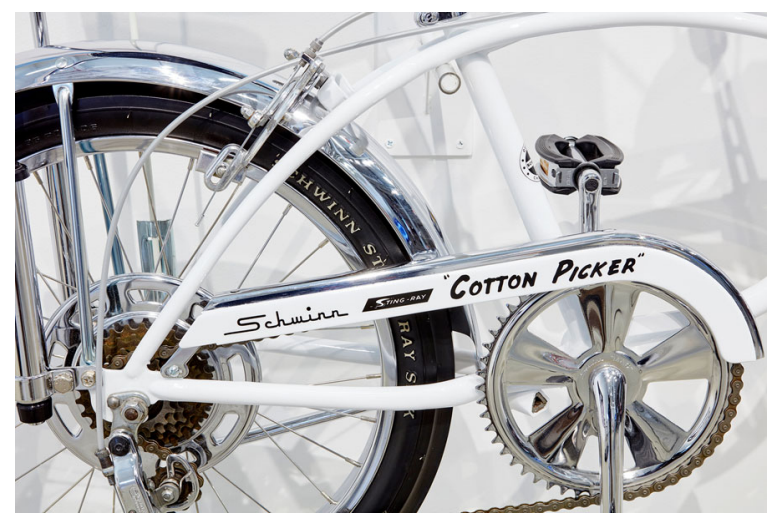

Figure 4. Miguel Luciano, Porto Rican Cotton Picker, detail (2011).1971 Schwinn Cotton Picker, restored and customized, flags. Image: Courtesy of the artist.

prompted me to look closer at any connections between Puerto Ricans and cotton picking. That research revealed a whole chapter in American history that is not very well known about one of our earliest migrations to the US. In the 1920s, cotton growers in Arizona recruited laborers from Puerto Rico to replace Mexican workers in the Arizona cotton fields. Immediately after the US occupation of Puerto Rico in 1898, Puerto Ricans were recruited for cheap labor by US corporations, from the sugar plantations of Hawaii to the cotton fields of Arizona. In 1917, Puerto Ricans were made US citizens under the Jones Act, but with limited rights. They became eligible for military conscription and were drafted in high numbers. Puerto Ricans have participated in every US military engagement since WWI, despite not having the right to vote, and no representation in Congress.

The Immigration Act of 1924 created new limitations and restrictions on foreign workers, so Puerto Ricans as new US citizens, but with limited rights and representation, came into focus as a new labor pool. The Arizona migration happened in 1926 and the story that I became interested in was of one particular family that stood up against exploitation and injustices from the very beginning. Felicitas Gómez and her family migrated from Juncos, Puerto Rico to work in the cotton fields in Pima County, Arizona (Figure 5). She was a little girl but her parents and grandparents worked for the cotton growers. The workers protested almost immediately. They were promised higher wages and better living conditions, but they were forced to live in barracks with no electricity and work in horrible conditions. They knew they had rights as citizens, and from the many new labor laws in Puerto Rico. The Phoenix, Arizona labor unions eventually offered support and helped organize with the Puerto Rican cotton workers. They formed one of the most significant labor protests in Arizona's history, which created short-term improvements, but eventually led the cotton growers to cancel the Puerto Rican labor program. Most of the families migrated to California and other parts of the southwest as migrant farm laborers. In California, Felicitas Gomez married Gonzalo Mendez, a naturalized citizen from Mexico, and they settled in Orange County. They had a unique situation in the 1940s; they were a family that went from being pickers to growers, after a farm became available for lease. That 


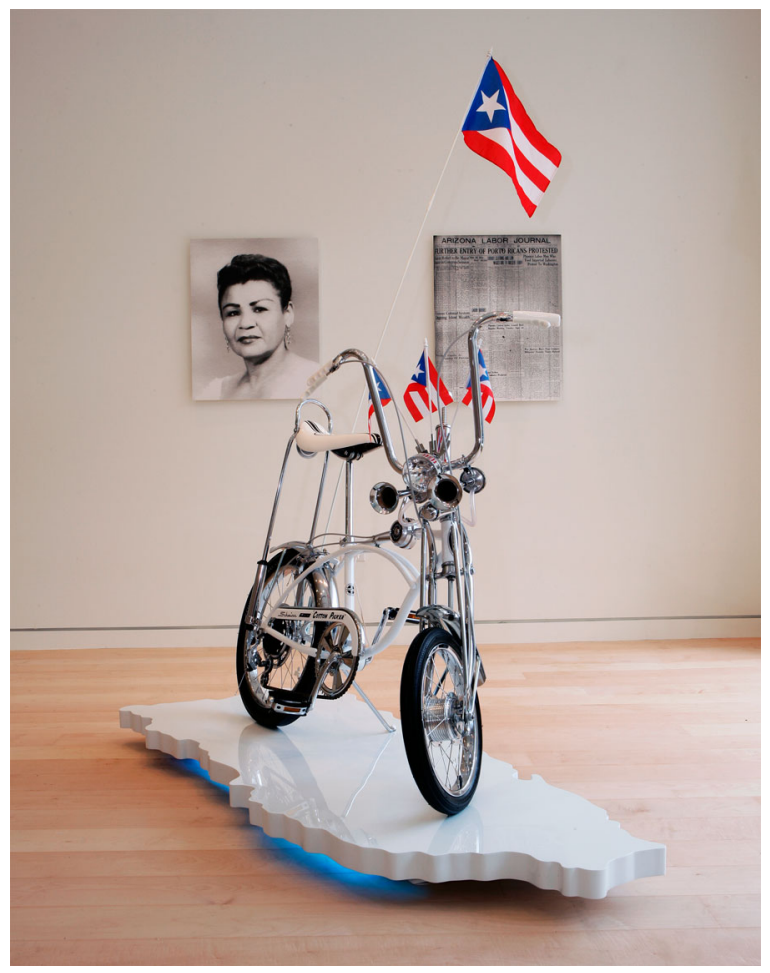

Figure 5. Miguel Luciano, Porto Rican Cotton Picker (2011) installation view with a 1926 issue of the Arizona Labor Journal with the headline "Further Entry of Porto Ricans Protested" and a portrait of Felicitas Mendez at BRIC, NY, 2017. Image: Courtesy of the artist.

farm was owned by the Munemitsu family, a Japanese family that was forced into an internment camp during WWII. The Mendez family leased the farm until the Munemitsus were released.

In 1945, the Mendezes went to enroll their kids in the local school in Orange County, but their kids were denied enrollment because they were not white. The Mendez family responded by taking the Westminster School District to court and used the money from the farm to pay the legal fees. There were five families represented in the case, all Puerto Rican and Mexican families. Mendez v. Westminster became a landmark civil rights case. California governor Earl Warren (in office 1943-1953) intervened in 1946 and changed the law. The Mendez family won, which made California the first state in the US to desegregate public schools. It is a huge part of American civil rights history that is not well known, but it is the precedent to Brown v. Board of Education [the landmark US Supreme Court Case that declared segregated schools unconstitutional] in 1954. Earl Warren later became a Supreme Court justice (from 1953 to 1969) and heard Brown v. Board of Education. Thurgood Marshall was the lawyer who won that case [and later became the first African-American justice to serve on the US Supreme Court, in office 1967-1991]. This history weaves together this really important history of Black and Latino communities fighting for equality and desegregating schools locally and nationwide. There is so much power in 
understanding and potentially teaching that [connected history]. We do not learn that way in school and for me it was important to bring those histories forward, to see how these struggles are shared struggles and have been fought in solidarity for a long time. There is power in understanding our connections with each other and with other colonized or oppressed peoples, in communities that organize and stand up for social justice and for equality. It is important to remember that the things that unite us are stronger than the things that divide us. It is critical that we understand that today. There is hope among younger generations; that is the one encouraging thing to think about in the moment that we are living in now. Too often we see these divides in our communities - Black and Brown - communities that have a lot in common and that often overlap with one another. In Harlem, where I live, the way they have overlapped for many years is well understood and we have many shared interests and histories.

Could you expand upon your research processes and how you uncover these histories and connections? What resources do you access for your research-based practice?

My initial research is informed by visual histories, by finding objects and artifacts that I do not fully understand or that I want to understand in more detail. They are often things that do not show up in traditional history texts. For example, many years ago, my mom sent me some postcards from New Orleans that featured different vintage advertisements for "Louisiana Porto Rican Sweet Potatoes." A lot of the images in these advertisements were overtly racist, stereotypical depictions of "Porto Ricans." She did not know what the history was of these products, so she sent me a bunch of the postcards, knowing that I would be interested in researching it further. I was in Puerto Rico at the time and I started doing research. I later went to the Center for Puerto Rican Studies at Hunter College in New York, and learned about the migration to Hawaii that happened through Louisiana in the early 1900s. California-based US sugar corporations recruited Puerto Rican laborers as early as 1900, to work on sugar plantations in Hawaii. Sugar was the golden crop of that era. In 1899, two hurricanes decimated Puerto Rico and its sugar industry, which created a worldwide shortage that increased the demands for Hawaiian sugar. The hurricanes left many sugar cane workers in Puerto Rico jobless and vulnerable. So, they were lured to Hawaii with the same promises of good pay and living accommodations; however, in actuality, people worked in enslaved-like conditions.

New Orleans was the first US port where Puerto Ricans arrived from the island by boat. They then traveled by train across the south, all the way up to California, where in San Francisco they embarked on a final boat to Hawaii. Many learned early on that they were being exploited. The corporations even had armed guards on the train at some point to prevent Puerto Ricans from escaping en route because people would get off at certain towns to look for work. In Louisiana, it was first our people and labor that traveled through its ports, followed by agricultural products from the island. The "Porto Rican Yam" is a yam variety originally imported from Puerto Rico that became a popular variety among Louisiana farmers in the 1940s, if not earlier. 
These Louisiana Porto Rican Yam and Sweet Potato labels became some of the first images in US print advertising that informed the American imagination about who Puerto Ricans are. Many were very racist, stereotypical, demeaning images and were the same kind of images being used to describe African-Americans in the South. Puerto Ricans were imagined in all of the same ways. These are some of the documents that start to visually unpack our migration histories. I wanted to look at how and why these images exist, and to then make work that commented back on those images and histories today. I looked at this as a colonial history that is still in process, exploring past and present relationships with the US, questioning how much has changed and how much has stayed the same. I did a whole series of paintings that started in the late 1990 s to the early 2000s. These produce labels, which were made into postcards of Southern memorabilia, became the Louisiana Porto Ricans series of paintings (Figure 6).

We wanted to turn to thinking about your work in terms of economic crisis on a national scale in our own moment. Puerto Rico has been in a recession since 2006, and the government had to continually borrow to pay operating expenses. Puerto Rico has a debt of $\$ 72$ billion, which far exceeds the $\$ 18$ billion bankruptcy filed by Detroit in 2013. Puerto Rico also has a $45 \%$ poverty rate and near-insolvent public health and pension systems. The island declared a form of bankruptcy this past May. You address the debt crisis in your work. Could you begin by explaining your work and expound upon the role of the US in restructuring the Puerto Rican economy?.

I think the root of this crisis - and I am not an economist - goes back to the problem of our colonial relationship, because we have never been able to negotiate the structure of

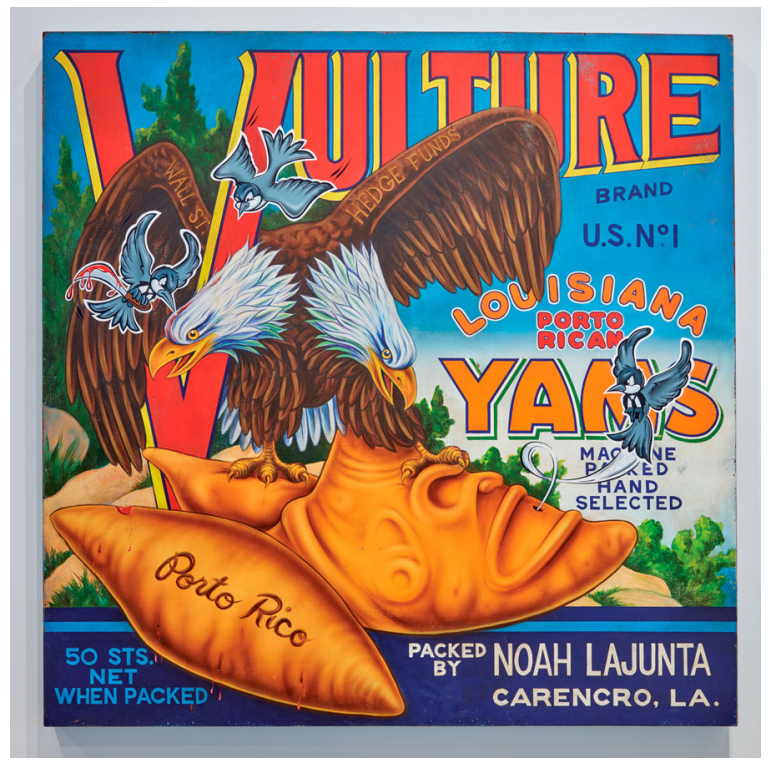

Figure 6. Miguel Luciano, Vulture Brand Yams (2017). Acrylic on canvas, over panel, $72 \times 72$ in. Image: Courtesy of the artist. 
our economy from any real position of power. The Puerto Rican economy has been designed and built around US business interests, and that is who has benefited the most over these years. The current debt is an extraordinary number and is completely unpayable. But, it is not simply because of government corruption or mismanagement, we are talking about an economic system that has been manipulated by US business interests and investors, in collusion with those in power in Puerto Rico over an extended period of time. Follow the money, and you will see who has benefited the most. There have been several attempts to audit the debt, in order to determine the legality of predatory lending practices and interest rates, but attempts have been blocked so far. I am sure much would be revealed. Meanwhile, there needs to be some serious consideration towards forgiving the debt entirely. The debt was unpayable before Hurricane Maria, and it is unfathomable to consider it now, when half the island is still without power and people are still struggling to survive.

What are your thoughts on the federal law The Puerto Rico Oversight, Management, and Economic Stability Act (PROMESA) that the US Congress enacted in 2016 and how does your work respond to it?

PROMESA is horrible. It will ensure the poverty of many generations to come in Puerto Rico. It is a bill that protects the interests of US investors and those who own the debt before any consideration of the well-being of the Puerto Rican people. It was supposed to be an economic relief bill. It is so offensive and misleading, even its name - PROMESA (promise) - reminds me of the era we are living in with Trump, and the co-option of fake news propaganda, even though this happened at the end of the Obama administration. The gesture is a false gesture, it is a cover for the Wall Street investors, banks and hedge fund groups that are still cashing in on Puerto Rico's vulnerability. It is going to make rich people richer and poor people poorer. The lower and middle classes will pay the biggest price. It is already happening but it is unconscionable to me that a bill would not do more to protect the most vulnerable in our community.

The numbers that we previously cited and which have been reported in multiple news outlets are in the billions, which are very abstract in terms of how this sum impacts individual lives. How do you go about visualizing this abstraction and does that visualization transfer to your work?

That is the thing. It is really hard to understand the numbers. The challenge then becomes how to translate them; how do you make this more legible to a broader audience? I think it is beyond the numbers. Rather than trying to explain triple-exempt bonds in an artwork, I can still point to patterns of exploitation that are clear. Look at the interest rates, for example. We start to see the debt skyrocketing over time because of interest rates applied to bonds that were impossible to pay back. They are looking at generations down the road who will still be paying this ridiculous debt and who are going to be left carrying that burden. It was organized in a very manipulative and predatory way, around a system that was destined to collapse. 
Efforts to audit the debt have been shut down by the current administration in Puerto Rico. I do not understand why a government would shut down an audit, except to protect people who may be at risk of exposure, and also to prove to US business interests what loyal subjects they are. This is a conservative, pro-statehood administration. It is very right wing and wants to demonstrate how fiscally conservative and responsible it can be, even if it means punishing its own people. Our leadership has been willing to acquiesce to US business interests, to the vulture funds, the banks, and the bondholders, etc. We do not have strong leadership. Eventually the people will force the leadership to respond or will change that leadership. I believe that. I think the experience of the hurricane has revealed how desperate things really are and how the people's priorities need to come before any bondholders' interests.

That is a large gap and distinction between Detroit and Puerto Rico's fiscal crisis. Detroit, as a US city, could apply for bankruptcy. Puerto Rico, as a US territory, like US states, lacks bankruptcy protections.

Detroit was $\$ 18$ billion compared to $\$ 72$ billion. It is like a whole other scale. That is part of the dilemma; our options feel very limited right now and so I think there are some dramatic changes that need to take place, but changes that begin to empower the people of Puerto Rico, not cripple us further. I have been thinking about it in different ways and as you asked, what is the role of art in this?

Yes, we were thinking specifically of two of your recent works: '51 (Se Acabaron Las Promesas) [The Promises Are Over] (2012-2017) and Puerto Rican Flag in Black and White, 2017. Both were on view at your Ride or Die solo exhibition at BRIC in Brooklyn in March 2017.

"Se Acabaron Las Promesas" (the promises are over) has been a slogan of the resistance. The Puerto Rican flag in black and white has become a symbol of protest against PROMESA and the debt crisis, throughout the island and in the US now, too. It is a symbolic mourning of the moment in which PROMESA issued a fiscal oversight board to restructure the economy, giving them power and authority over the local government. It completely undermines Puerto Rico's constitution and was like removing the veil on Colonialism 2.0. The flag protests the idea of the US solving our problem with solutions that make things worse for Puerto Rico.

The work '51 (Se Acabaron Las Promesas) (Figure 7) is a sculptural project based on a vintage Schwinn bicycle from 1951. I restored and customized it, and painted it in black and white, which refer to the colors of protest, but also represent the colors of the Puerto Rican Nationalist (pro-independence) party. In an exhibition context, there are wall labels and didactic texts that often help to unpack the symbolism in the work. The title alludes to the number 51 as a reference to Puerto Rico as the fifty-first state, while lamenting the year 1951, which was the year before Puerto Rico officially became a Commonwealth territory with the ratification of the Puerto Rican Constitution (1952). The year 1951 marked the end of an era in this sense, as Puerto Rico created a neocolonial agreement in chartering the Commonwealth 




Figure 7. '51 (Se Acabaron Las Promesas /The Promises Are Over) (2012-2017). 1951 Schwinn Hornet, custom platform, LEDs, flags. Image: Courtesy of the artist.

status. We have continued to be a colony by another name to this day. The bicycle is raised on a platform that is shaped in the silhouette of Puerto Rico, also painted in black, but lit up from the bottom. While the work represents a certain kind of mourning of our political past, it also reflects the energy of protest and resistance that is proudly part of our present.

\section{Are you working on any projects at the moment that are reflective of the public} service closures on the island?

The closure of schools, hospitals, and other public services has been devastating. I am currently doing a project that examines the crisis on the island and its relationship to the diaspora, to look at how our communities have responded to crisis with both resistance and resilience, from the post-civil rights era to the post-Hurricane Maria present. Part of the idea is to engage community members and activists here in East Harlem that were involved in community struggles of the 1960s and 1970s, and to put those histories in conversation with what is happening now. We are approaching the 50-year anniversary of the Young Lords in East Harlem, who were a radical group of young, Puerto Rican activists working for social justice. They were directly inspired by the Black Panthers, and on a community level they organized around issues of health, food, housing, and education - basic quality of life issues that remain in crisis 
today, both on the island and in East Harlem. They also focused on ending police violence and the decolonization of Puerto Rico as top priorities. The project will start with a public exhibition in Harlem, where I am hoping to enlarge historic images of the Young Lords and their different community actions as billboards that will be placed at or near the location of the original event. I am working with former members of the Young Lords to organize the project. The idea is to make visual this powerful history while the generation of the 1960s is still here to tell the stories. These are living histories in a community that is rapidly changing. There will be organized walking tours that connect younger audiences to the voices of our elders in an effort to move this history forward.

The second part of the project will be a series of Community Action Workshops that look at creative, actionable solutions to social justice issues in our communities today. I am interested in focusing on some of the same platform issues of health, food, housing, and education and want to create a space where folks from both Puerto Rico and El Barrio [the New York City neighborhood of East Harlem] can come together in some creative solution building. I am particularly interested in issues around food and food sustainability. There are a lot of young innovative people on the island who have been getting into farming and other kinds of small businesses that have to do with healthy food and healthy living in an environmentally and ecologically conscious way. Farms were completely wiped out in the hurricane, on an island that already imports $80 \%$ or more of its food supply, which has raised awareness about the importance of food sustainability. I am inspired by those working in the earth, I think there is something key about grounding ourselves, literally in this moment, in the earth itself. At a time when the economy and everything else is falling apart, the land is still resilient and people have begun to refocus on this. From independent farmers, to informal urban agriculture, community gardens, I am interested in how food can be one of the things we focus on as a way to promote traditions that we have grown away from and that everyone can get involved in. It is about taking care of ourselves, our land, and our bodies. I am still working out the details, but I hope to invite chefs, food activists, and community members into a shared space of exchange that can be hands-on and culminate in a community-wide food event that is both educational, environmentally conscious, and delicious.

I want the workshops to focus on solution building that is actionable and realizable, and that can be applicable and effective - not just symbolic - but actually have an impact on the way we live and think. That is the goal. I think a lot of what I do is work with the symbolism through objects in a more traditional art context. This is thinking outside of that a bit, as the Community Action Workshops are more of a process-focused, socially engaged art practice.

\section{Lastly, another issue that we are examining is the role of the art market. How do you sustain your practice as a self-represented artist outside of the gallery system?}

For me it has all been outside of the gallery. I do not have a commercial gallery that I work with. I have been fortunate to be able to work with institutions or foundations that have been supportive in commissioning projects and funding new work. A lot 
of that means writing proposals and finding ways to fund my ideas, but in the last few years I am really grateful that I have been able to find some support in this regard. Some of the projects have built momentum, but it is not a traditional way of doing things necessarily. It is also really difficult to have your commercial practice sustain your work entirely. It is possible, but perhaps just as difficult. So I am not saying that is not a possibility or an eventuality, but it is not the focus of what I am doing right now. Maybe there is some freedom in terms of what the work looks like if there is not a commercial focus. These workshops and the other things are more about bringing people together and trying to create an experience that extends from the work. That is not something that is commodified. It is not anything like that, nor will it ever be. That is the work right now, and it is happening through other modes of support. We will see what grows from here.

\section{Disclosure Statement}

No potential conflict of interest was reported by the authors.

MIGUEL LUCIANO (b. San Juan, Puerto Rico) received his MFA from the University of Florida. His work has been exhibited nationally and internationally, including exhibitions at the Mercosul Biennial, Brazil; La Grande Halle de la Villette, Paris; El Museo del Palacio de Bellas Artes, Mexico City; the Ljubljana Biennial, Slovenia; the San Juan Poly-Graphic Triennial, Puerto Rico; Zverev Center for Contemporary Art, Moscow; and the Smithsonian Institution in Washington, DC. He is the recipient of the Louis Comfort Tiffany Award Grant, the Joan Mitchell Foundation Painters and Sculptors Award Grant, the NYFA award for painting, and the Artists and Communities Grant from the Mid Atlantic Arts Foundation. His work is featured in the permanent collections of the Smithsonian American Art Museum, DC; the Brooklyn Museum, NY; El Museo del Barrio, NY; the Newark Museum, NJ; and the Museo de Arte de Puerto Rico. Luciano recently created a public art project in Nairobi, Kenya as a fellow of the Smart Power Program, an initiative of the Bronx Museum of the Arts and the US Department of State's Bureau of Educational and Cultural Affairs.

MARISA LERER and CONOR MCGARRIGLE, respectively from Manhattan College (New York) and Dublin Institute of Technology, are the Guest Editors of this Special Issue.

\section{Note}

1. Tiffany Hsu, "More Angelenos Are Becoming Street Vendors Amid Weak Economy," Los Angeles Times, September 6, 2014, http://www.latimes.com/business/la-fi-streetvendors-20140902-story.html. 